\title{
Analisis Gerak Teknik dan Performa Memanah Nomor 70 Meter Recurve Atlet PPLP Panahan Daerah Istimewa Yogyakarta
}

\author{
Luluk Septiana ${ }^{1}$, Widiyanto ${ }^{2}$, Carles Nyoman Wali ${ }^{2}$ \\ ${ }^{1}$ SMK Muhammadiyah Galur, Indonesia \\ ${ }^{2}$ Universitas Negeri Yogyakarta, Indonesia
}

Diterima: 21 Agustus 2020. Direvisi: 31 September 2020. Disetujui: 6 Oktober 2020

\begin{abstract}
Abstrak Penelitian ini bertujuan untuk mengungkap kinerja gerak teknik dan performa memanah jarak 70 meter recurve putri pada kejurnas antar PPLP di Semarang tahun 2015. Penelitian ini merupakan penelitian deskriptif kuantitatif dengan variabel: gerak teknik memanah dan kemampuan fisik memanah. Instrumen yang digunakan yaitu; (1) angket, yang berisi kisi-kisi analisis kinerja gerak teknik memanah yang telah divalidasi oleh ahli biomekanika dan teknik memanah; (2) handycam, untuk melakukan pengamatan. Subjek penelitian dalam penelitian ini adalah atlet panahan putri yang mengikuti kejurnas panahan jarak 70 meter recurve antar PPLP di Semarang tahun 2015 yang berjumlah 3 atlet. Teknik analisis data dalam penelitian ini yaitu deskriptif kuantitatif. Hasil penelitian menunjukkan bahwa: (1) Kinerja gerak teknik memanah pada tahap cara berdiri (stance), memasang ekor panah (nocking), posisi setengah tarikan (set up), menarik tali (drawing), penjangkaran (anchoring), menahan sikap memanah (holding), membidik (aiming), melepaskan anak panah (release), gerak lanjut (followthrough) berada pada kategori baik. (2) Performa atlet memanah PPLP DIY masih kurang, terlihat dari hasil perolehan skor pada setiap rambahan selalu menurun.
\end{abstract}

Kata Kunci: Analisis biomekanika, gerak teknik panahan, performa, PPLP DIY

Abstract This research aimed to reveal the capability of technical movement and the performed by female archers to shoot arrow in 70 meters recurve distance on the championship among PPLP in 2015 in Semarang. This research was a descriptive quantitative research with variables the technical movement and the physical ability of shooting arrow. The instruments used are: (1) questionnaire, containing the blue print of analysis of the capability of technical movement in shooting arrow which has been validated by the expert of biomechanic and the technique of shooting arrow; (2) handycam, to carry out the observation. The research subjects is female archers who joined the championship among PPLP in Semarang in 2015 totaling 3 archer. The result of this research shows, (1) technical movement of shooting arrow on the phase of stance, nocking, set up, drawing, anchoring, holding, aiming, releasing and follow through is classified in "good" category; (2) the performance of the athletes of archery of PPLP is not maximum, it can be seen from the decrease tendency in obtaining additional score.

Keyword: Biomechanic analysis, technical movement of archery, performance, PPLP DIY

\section{PENDAHULUAN}

Olahraga panahan adalah meregangkan tali busur dan panah selama beberapa waktu dengan tangan dan harus tetap menjaga posisi tubuh dan busur untuk tetap stabil (Zanevskyy, 2008, p.4). Panahan adalah olahraga dengan mendorong anak panah ke dalam target dengan menggunakan busur, (Lee, 2008, p.343). Tujuan akhir dari memanah adalah menembak anak panah kepermukaan sasaran (target face) setepat mungkin. Dalam olahraga panahan, atlet bersaing untuk mendapatkan poin dengan menembakkan sejumlah set anak panah dalam waktu yang ditetapkan (Takai \& Hideaki; et all, 2012). Dari paparan di atas dapat disimpulkan bahwa olahraga panahan merupakan meregangkan tali busur dan panah selama beberapa waktu dengan tangan dengan tetap menjaga kestabilan tubuh dan busur kemudian melepaskan anak panah dari busur ke arah sasaran (target face) dengan tujuan mendapatkan skor yang tinggi.

Olahraga panahan membutuhkan sentuhan jiwa yang halus, kesabaran, keuletan, konsentrasi dan ketahanan mental yang tinggi serta memiliki tingkat kecemasan yang tinggi. Sehingga unsur-unsur seperti postur tubuh, teknik dasar, mekanisme gerak, mentalitas dan kondisi fisik sebagai sebuah kesatuan harus dimiliki oleh seorang pemanah. Seperti sebuah seni, olahraga panahan sangat kompleks tidak seperti yang terlihat yaitu hanya menarik tali busur dan melepaskan panah. Kekuatan dan daya tahan otot lengan sangat diperlukan dalam panahan untuk dapat menarik tali busur dengan stabil dan seimbang, karena beban tarikan tali busur tersebut mencapai 40-44 pon dan dilakukan berkali-kali dalam sebuah pertandingan. Selain itu, gerak teknik atau keteram- 
pilan dalam memanah juga harus dikuasai untuk mendukung performa memanah.

Pada dasarnya, teknik memanah pada dasarnya ada sembilan langkah/tahapan, yaitu: (1) cara berdiri (stance), adalah adalah sikap atau posisi kaki pada lantai atau tanah, yaitu kaki sebagai tumpuan harus kuat menopang tubuh saat melakukan gerakan memanah sehingga posisi tubuh tetap seimbang; (2) memasang ekor panah (nocking), adalah gerakan menempatkan atau memasukkan ekor panah ke tempat anak panah pada tali; (3) posisi setengah tarikan (set up), merupakan tarikan awal sebelum menarik tali busur secara penuh; (4) menarik tali (drawing), adalah gerakan menarik tali busur sampai menyentuh bagian dagu, bibir dan hidung; (5) penjangkaran (anchoring), adalah gerakan menjangkarkan tangan penarik pada bagian dagu atau rahang; (6) menahan sikap memanah (holding), adalah menstranfer beban; (7) membidik (aiming), adalah gerakan mengarahkan atau menempatkan titik alat pembidik (visir) pada tengah sasaran atau titik sasaran; (8) melepaskan anak panah (release), adalah gerakan melepaskan tali busur dengan cara merilekskan jari-jari penarik tali; (9) gerak lanjut (follow through), adalah bagan yang dilakukan setelah release dan bukan merupakan gerakan yang terpisah. (Pelana \& Oktafiranda, 2010). Oleh karena itu setiap tahapan merupakan urutan gerakan yang stabil. Tahap-tahap tersebut sangat kompleks dan harus dipelajari satu-persatu secara detail. Pada proses melatih gerak teknik tidak cukup hanya dengan pengamatan saja, namun harus didukung dengan ilmu pengetahuan dan teknologi. Dalam ilmu olahraga dikenal suatu disiplin ilmu yang secara khusus mempelajari gerakan atlet saat bertanding. Ilmu tersebut dikenal sebagai ilmu biomekanika yaitu ilmu pengetahuan yang dapat mendukung dalam proses pembentukan teknik seperti analisis gerak melalui pendekatan biomekanika. (Hmill, 2019).

Olahraga panahan dilihat dari segi biomekanika terdapat pada klasifikasi keterampilan yaitu melontarkan objek untuk mencapai ketepatan maksimum. Keterampilan dalam memanah didefinisikan sebagai kemampuan untuk menembak panah ke target yang diberikan dalam rentang waktu tertentu dengan akurasi (Artanayasa, 2015). Pada nomor 70 meter revurve merupakan jarak yang terjauh untuk putri pada ronde FITA. Tingkat kesulitan pada jarak yang lebih jauh tentunya akan semakin tinggi, sehingga jika dilihat dari kajian biomekanika membutuhkan teknik khusus agar anak panah tetap tepat pada sasaaran. Dilihat dari karakteristiknya, prinsip dasar olahraga panahan adalah melepaskan panah melalui lintasan tertentu menuju sasaran pada jarak tertentu. Melihat dari karakteristik olahraga panahan tersebut dapat diketahui bahwa anak panah tidak akan dapat bergerak pada lintasan yang lurus pada sasaran dalam jarak 70 meter. Sebuah anak panah akan berjalan pada lintasan parabola. Hal tersebut dipengaruhi oleh beberapa gaya yang bekerja pada anak panah tersebut. Untuk mengantisipasi hal-hal tersebut, seorang atlet harus memahami bagaimana teknik yang harus dilakukan agar anak panah tetap menancap tetap pada sasaran. Nampaknya, olahraga panahan bukanlah suatu olahraga yang mudah bagi atlet yang belum terlatih, bahkan atlet yang terlatih pun sering kali mengalami kesulitan (Prasetyo, 2019)

Pada ronde FITA recurve jarak 70 meter tentunya ada beberapa teknik yang berbeda jika dilihat dari kajian biomekanika, karena jarak mempengaruhi mekanisme gerak teknik yang harus dilakukan agar anak panah tetap tepat pada target. Untuk itu sangat penting dilakukan perhitungan dengan kajian biomekanika. Dengan demikian hal-hal yang perlu dilakukan adalah: (a) Menganalisis gerak teknik memanah, kemudian hasil analisis yang tepat dimanfaatkan sebagai sumbangan dalam pembinaan prestasi khususnya efisiensi gerak; (b) Mengetahui faktor-faktor penghambat efisiensi gerak teknik memanah. (Nasution, 2003)

Biomekanika adalah sebuah cabang ilmu olahraga yang mempelajari gerakan-gerakan tubuh atau atlet. Analisis kinerja olahraga secara biomekanika merupakan metode dengan tujuan menentukan kinerja dari teknik olahraga tertentu, yaitu untuk menambah pemahaman tentang mekanisme yang mempengaruhi kinerja, karakterisasi atlet, dan memberikan wawasan ke dalam cedera.

Secara umum manfaat yang didapat dalam mempelajari Biomekanika Olahraga adalah untuk memperbaiki teknik dengan melakukan analisis yang dilakukan dan mencegah cidera olahraga. Aplikasi biomekanka olahraga yaitu diharapkan untuk meningkatkan kinerja atau performa, untuk mencegah cedera (Sudarmada \& Kusuma, 2015) Jadi manfaat utama mempelajari biomekanika adalah memperbaiki penampilan dan mencegah cidera. Selain itu ada beberapa manfaat lain selain dua manfaat utama yang disebutkan diatas, yaitu; (1) membantu dalam proses mempelajari atau mengajarkan satu teknik tertentu; (2) dapat 
menciptakan teknik baru dalam upaya memaksimalkan prestasi yang sudah didapat; (3) memahami desain alat-alat atau perlengkapan olahraga yang dipakai dan disesuaikan dengan kebutuhan dari cabang olahraga yang dimaksud; (4) dapat dipakai dalam pemanduan bakat untuk mencari bibit yang potensial untuk dikembangkan prestasinya secara optimal.

Teknik pada cabang olahraga mempunyai karakteristik masing-masing. Pelatih harus memahami karakteristik masing-masing cabang olahraga. Pemakaian peralatan serta fasilitas yang sering digunakan harus ada kesesuaian dengan teknik serta pemakaiannya harus benar dan tepat. Diperlukan analisis biomekanika secara teliti dan tepat untuk mengetahui kesalahan-kesalahan pada saat melakukan gerak teknik. Hal tersebut dapat dilakukan menggunakan analisis video, sehingga pelatih dapat memberikan perbaikan yang tepat. Untuk bisa secara efektif menganalisis dan meningkatkan teknik, pelatih di masa kini membutuhkan pemahaman mendalam tentang biomekanika (Hamill \& Knutzen, 2003). Para pelatih panahan diharapkan mampu melakukan analisis gerak teknik dari sudut pandang biomekanika, sehingga dapat memberikan informasi teknik yang benar dan melakukan latihan terhadap gerak teknik yang belum benar secara tepat kapada anak latih, serta tetap memberikan latihan-latihan yang dapat mendukung performa dalam panahan khususnya saat bertanding. Dari pendapat di atas, dapat disimpulkan bahwa untuk bisa mendapatkan performance yang optimal pada cabang olahraga panahan diperlukan pemahaman tentang mekanisme yang mempengaruhi kinerja, karakterisasi atlet, dan memberikan wawasan ke dalam cedera yang dapat diperoleh dari analisis menggunakan kajian biomekanika.

Biomekanika adalah ilmu utama olahraga yang berfokus pada teknik gerakan, sehingga pelatih harus menggunakan prinsip-prinsip biomekanika dalam membantu atlet bergerak dengan aman dan efektif. Dengan adanya analisis biomekanika olahraga maka dapat dimunculkan teknik-teknik dan alat-alat baru yang didesain lebih maju untuk mendukung sebuah penampilan, (Curran \& Frossard, 2012) Pelatih menggunakan analisis untuk mengetahui gerak teknik yang dilakukan atlet, sehingga dapat memberikan perbaikan dan resep intervensi untuk membantu atlet meningkatkan kinerja dalam melakukan gerak teknik memanah. Biomekanika juga memungkinkan pelatih untuk mengidentifikasi latihan dan kegiatan fisik yang berkontribusi untuk pembangunan fisik berbagai kelompok otot dan komponen kebugaran (Knudson, 2007)

Melatih teknik dan fisik seorang atlet harus mendapatkan perhatian khusus dalam upaya untuk menghasilkan atlet-atlet andal. Karena dengan teknik yang baik maka akan mebuat gerak atlet akan efektif dan efisien, serta akan terhindar dari cidera. Analisis teknik secara biomekanika, dapat digunakan oleh para pelatih dan ahli biomekanika untuk menganalisa teknik para atlet dunia dalam latihan maupun perlombaan dan juga dalam penciptaan peralatan dalam memanah untuk mendukung penampilan atlet saat bertanding. Saat ini belum banyak pelatih yang melakukan analisis dengan teknik analisis biomekanika, dikarenakan keterbatasan alat yang mendukung untuk menganalisis, seperti aplikasi biomekanika dan alat perekam gerak (Komarudin, 2013)

Selain teknik, faktor yang dominan untuk mendukung performa seorang atlet adalah faktor kebugaran jasmani/kemampuan fisik. Unsur teknik dan fisik yang baik akan akan mempengaruhi keajegan dalam melakukan gerakan teknik. Selain konsentrasi juga mempengaruhi keberhasilan panahan. Seperti yang diungkapkan oleh (Lee, 2009). Kemampuan fisik merupakan pondasi dari prestasi olahragawan, sebab teknik/gerak, taktik dan mental (psikhis) akan dikembangkan dengan baik jika memiliki kualitas fisik yang baik. Oleh sebab itu, pada olahraga panahan kemampuan fisik sangat dibutuhkan terutama kekuatan dan daya tahan otot-otot lengan.

Faktor pendukung paling dominan dalam aktivitas olahraga adalah faktor fisik, dan daya tahan tubuh karena sasaran utama dari latihan fisik adalah untuk meningkatkan kemampuan kebugaran jasmani (energy fitness) dan kebugaran otot (muscular fitnes) (Sukadiyanto, 2010). Fisik merupakan pondasi dari prestasi olahragawan, sebab teknik, taknik, dan mental akan dikembangkan dengan baik jika mempunyai kualitas fisik yang baik. Kondidi fisik sangat menunjang dalam mempersiapkan latihan dan pertandingan, sehingga atlet tidak mengalami kelelahan yang berarti dan akan terhindar dari cedera yang akan menggangu penampilan/performa.

Kekuatan dan daya tahan otot yang terlatih sangat diperlukan untuk dapat melakukan teknik memanah dengan benar karena untuk menarik tali busur yang dilakukan berkali-kali dalam sebuah pertandingan yang digunakan secara dominan adalah otot-otot 
lengan. Dengan begitu tidak hanya unsur teknik yang diperlukan dalam keberhasilan memanah, namun unsur fisik sangat diperlukan untuk mendukung prestasi memanah terutama pada daya tahan otot lengan. (Furqon, 2003) Tanpa kekuatan dan daya tahan otot lengan yang baik pemanah tidak akan mampu menarik dan menahan tali busur secara maksimal dan seimbang selama beberapa waktu, sehingga konsentrasi untuk membidik menjadi tidak akurat. Dengan kekuatan dan daya pada otot-otot lengan, maka lengan penahan busur akan tetap seimbang dan dapat menarik busur panah dengan stabil. Jika hal tersebut dapat tercapai, maka akan menghasilkan release yang halus, sehingga anak panah dapat tepat berada pada sasaran yang dituju. (Muchtamadji, 1999)

Prestasi panahan dapat disalurkan melalui organisasi-organisasi panahan, salah satunya adalah PPLP (Pusat Pendidikan dan Latihan Olahraga Pelajar) panahan di DIY. Perekrutan anggota PPLP panahan DIY harus dengan seleksi yang ketat, kompetisi yang terencana, teratur dan berkelanjutan. Pengamatan di lapangan menunjukkan bahwa atlet masih kurang bersemangat dalam melakukan latihan fisik karena atlet panahan masih kurang menyadari penting unsur fisik terutama pada kekuatan dan daya tahan otot lengan untuk mendukung performa memanah pada saat pertandingan. Pada kenyataannya setelah diamati pada setiap kompetisi dan latihan, perolehan skor pada atlet PPLP panahan DIY di setiap rambahan selalu menurun. Ini tampak dari skorsheet setiap atlet bahwa berurutan dari tembakan 1 sampai ke 6 selalu menurun. Fenomena tersebut menunjukkan bahwa performa dalam memanah sangat dipengaruhi oleh faktor fisik khususnya pada kekuatan daya tahan otot lengan. Performa seorang atlet dapat diamati pada saat pertandingan melalui peroleh skor pada saat pertandingan. Performa yang baik akan menghasilkan skor yang konsisten pada setiap tembakan, sehingga grafik perolehan skor pada setiap rambahan tidak mengalami penurunan. Hasil tembakan yang konsisten akan menghasilkan penjumlahan skor yang lebih tinggi, sehingga prestasi akan tercapai secara optimal.

Permasalahan dilapangan yang dialami oleh atlet panahan adalah selalu mengalami penuruna skor pada setiap rambahan dalam suatu pertandingan. Ini menunjukkan performa atlet panahan masih harus ditingkatkan terutama pada kekuatan dan daya otot lengan. Dilihat dari PON yang diwakilkan oleh bebe- rapa atlet PPLP pada tahun 2012, DIY hanya dapat membawa 2 emas dan 2 perak dari 11 atlet. Pada kompetisi-kompetisi yang telah dilakukan perolehan skor masih selalu menurun pada setiap rambahan. Hal tersebut tentu saja dipengaruhi oleh faktor gerak teknik dan kondisi fisik terutama pada kekuatan dan daya otot lengan dari masing-masing atlet. Penelitian ini diharapkan dapat menganalisis gerak teknik dan performa pada atlet panahan berdasarkan kajian biomekanika sehingga dapat dijadikan sebagai acuan dalam penyusunan program dan metode melatih gerak teknik serta membangun performa yang optimal.

\section{METODE}

Metode dalam penelitian menggunakan metode survei dengan melakukan observasi terhadap kinerja gerak teknik dan performa memanah nomor 70 meter recurve pada atlet putri PPLP panahan DIY pada saat pertandingan. (Sandjaja , Hariyanto, \& Albertus, 2006), penelitian deskriptif bertujuan untuk mendeskripsikan gejala-gejala yang ada pada masa itu. Penelitian deskriptif hanya memaparkan obyek apa adanya secara sistematik dengan menekankan pada data faktual. Penelitian ini merupakan penelitian kuantitatif karena hasil penelitian merupakan uraian dari data yang berupa angka.

Penelitian ini dilakukan di Lapangan PPLP Panahan Sorowajan pada hari Selasa, 5 Mei 2015 pada saat latihan, yaitu untuk menganalisis teknik memanah atlet panahan puteri yang mengikuti kejuaraan nasional panahan jarak 70 meter recurve antar PPLP di Semarang. Sedangkan untuk menganalisis kemampuan fisik dilakukan di Stadion Diponegoro Semarang pada hari Senin, 11 Mei 2015 pada saat kejuaraan nasional panahan antar PPLP. Subjek penelitian ini adalah atlet panahan puteri yang terdaftar sebagai atlet PPLP DIY pada nomor recurve jarak 70 meter dalam kejuaraan nasional di Semarang yang berjumlah 3 orang atlet.

Subjek penelitian dalam penelitian ini adalah atlet panahan putri yang mengikuti kejurnas panahan nomor 70 meter recurve antar PPLP di Semarang tahun 2015 yang berjumlah 3 atlet.

Instrumen yang digunakan untuk pengamatan hasil teknik memanah adalah dengan kisi-kisi pelaksaan gerak teknik memanah dengan indikator-indikator yang harus dicapai dalam setiap tahap gerak teknik memanah. Pengukuran teknik memanah tersebut nantinya 
akan dilakukan penganalisaan yang dilakukan oleh ahli. Sedangkan untuk analisis performa memanah menggunakan handycame untuk merekam video saat bertanding yang dilakukan oleh atlet PPLP panahan DIY pada kejuaran nasional antar PPLP di Semarang tahun 2015.

Pengumpulan data untuk kinerja gerak teknik memanah nomor 70 meter recurve atlet PPLP panahan DIY dalam penelitian ini menggunakan angket yang berisisi kisi-kisi gerakan tahapan dalam memanah berurutan mulai dari cara berdiri (stance), memasang ekor panah (nocking), posisi setengah tarikan (set up), menarik tali (drawing), penjangkaran (anchoring), menahan sikap memanah (holding), membidik (aiming), melepaskan anak panah (release) dan gerak lanjut (follow through) yang dilakukan oleh atlet PPLP panahan DIY pada saat latihan. Pengambilan gambar rekaman dilakukan dari berbagai arah yaitu dari samping kanan, samping kiri, dan atas agar gambar yang diperoreh lebih akurat. Sedangkan untuk mengetahui performa memanah jarak 70 nomor recurve atlet PPLP panahan DIY adalah merekan gambar dan menganalisis hasil skor pada saat pertandingan kejuaran nasional antar PPLP di Semarang tahun 2015.

Teknik analisis data penelitian ini yaitu: (1) Penilaian angket yang dilakukan oleh expert judgement untuk menganalisis gerak teknik. Sehingga diperoleh hasil analisis data dapat diklasifikasikan menurut (Azwar, 2008).

Tabel 1. Teknik memanah atlet PPLP DIY

\begin{tabular}{ll}
\hline Interval Skor & Kategori \\
\hline 3,26 s.d 4,00 & Baik \\
2,51 s.d 3,25 & Cukup Baik \\
1,76 s.d 2,50 & Kurang \\
1,00 s.d 1,75 & Tidak Baik \\
\hline
\end{tabular}

Kemudian ditarik kesimpulan dengan keterangan; (a) baik, jika rerata skor pada indikator keseluruhan berada pada rentang 3,26 s.d 4,00; (b) cukup baik, jika rerata skor pada indikator keseluruhan berada pada rentang 2,51 s.d 3,25; (c) kurang baik, jika rerata skor pada indikator keseluruhan berada pada rentang 1,76 s.d 2,50; (d) tidak baik, jika rerata skor pada indikator keseluruhan berada pada rentang 1,00 s.d 1,75. (2) Pengamatan rekaman video terhadap kinerja teknik memanah atlet putri yang mengikuti kejurnas panahan nomor 70 meter recurve antar PPLP di Semarang tahun 2015 dengan software kinovea. (3) Pengamatan rekaman video hasil pertandingan pada kejurnas panahan nomor 70 meter recurve antar PPLP di Semarang tahun 2015.

\section{HASIL DAN PEMBAHASAN}

Setelah dianalisis dengan bantuan software komputer diperoleh rerata kinerja gerak teknik atlet panahan PPLP DIY sebesar= 3,75. Rerata skor tersebut berada pada interval kelas 3,26 s.d. 4,00 kategori baik; dengan demikian dapat dikatakan bahwa kinerja gerak teknik panahan atlet putri yang mengikuti kejuaraan nasional panahan jarak 70 meter recurve antar PPLP berada pada kategori baik. Adapun distribusi kinerja gerak teknik panahan berdasarkan pengkategoriannya dapat dilihat pada Tabel 2.

Tabel 2. Kinerja teknik memanah

\begin{tabular}{lccl}
\hline Interval skor & $\mathrm{F}$ & Persentase & Kategori \\
\hline 3,26 s.d 4,00 & 3 & $100 \%$ & Baik \\
2,57 s.d 3,25 & 0 & $0 \%$ & Cukup baik \\
1,76 s.d 2,50 & 0 & $0 \%$ & Kurang baik \\
1,00 s.d 1,75 & 0 & $0 \%$ & Tidak baik \\
\hline
\end{tabular}

Sebelum dianalisis pada tiap-tiap faktor untuk kinerja gerak teknik memanah, berikut ini dapat diuraikan perhitungan rerata skor seluruh atlet pada tiap-tiap faktor. Hasil perhitungan rerata tiap-tiap faktor dapat dilihat pada Tabel 3.

Tabel 3. Perhitungan rerata seluruh indikator pada tiap-tiap faktor

\begin{tabular}{lccccc}
\hline $\begin{array}{l}\text { Nama } \\
\text { Faktor }\end{array}$ & $\begin{array}{c}\text { Nomor } \\
\text { indikator }\end{array}$ & $\begin{array}{c}\text { Jumlh } \\
\text { item }\end{array}$ & N & $\begin{array}{c}\text { Rata- } \\
\text { rata }\end{array}$ & Kategori \\
\hline Stance & 1 & 1 & 3 & 4 & Baik \\
Knocking & $2-3$ & 2 & 3 & 4 & Baik \\
Set up & $4-8$ & 5 & 3 & 4 & Baik \\
Drawing & $9-12$ & 4 & 3 & 3,58 & Baik \\
Penjang- & $13-16$ & 4 & 3 & 3,58 & Baik \\
karan & $17-19$ & 5 & 3 & 3,67 & Baik \\
Holding & $20-21$ & 2 & 3 & 3,67 & Baik \\
Aiming & $22-25$ & 4 & 3 & 3,67 & Baik \\
Release & $26-28$ & 3 & 3 & 3,89 & Baik \\
Followtrog & & & & & \\
\hline
\end{tabular}

Berdasarkan Tabel 3, diketahui bahwa kinerja gerak teknik memanah atlet PPLP Panahan nomor 70 meter recurve puteri pada tahap cara berdiri (stance), memasang ekor panah (nocking), posisi setengah tarikan (set up), menarik tali (drawing), penjangkaran (anchoring), 
menahan sikap memanah (holding), membidik (aiming), melepaskan anak panah (release) dan gerak lanjut (follow through) berada pada kategori baik, sehingga tidak ada tahapan yag masuk dalam kategori cukup baik, kurang baik, dan tidak baik.

Berikut disajikan analisis data secara lebih rinci masing-masing faktor kinerja gerak teknik memanah; Stance, berdasarkan analisis data dengan bantuan software komputer diperoleh rerata kinerja gerak teknik memanah pada tahap stance sebesar= 4,00. Adapun distribusi kinerja gerak teknik memanah untuk tahap stance pada atlet panahan PPLP DIY berdasarkan pengkategoriannya dapat dilihat pada Tabel 4.

Tabel 4. Distribusi kinerja gerak teknik memanah pada tahap stance

\begin{tabular}{lccl}
\hline Interval skor & F & Persentase & Kategori \\
\hline 3,26 s.d 4,00 & 3 & $100 \%$ & Baik \\
2,57 s.d 3,25 & 0 & $0 \%$ & Cukup baik \\
1,76 s.d 2,50 & 0 & $0 \%$ & Kurang baik \\
1,00 s.d 1,75 & 0 & $0 \%$ & Tidak baik \\
\hline
\end{tabular}

Tabel 4 memperlihatkan bahwa kinerja gerak teknik memanah untuk tahap stance atlet puteri PPLP DIY pada nomor 70 meter recurve 3 atlet sebagai subjek penelitian (100\%) berada pada kategori baik, tidak ada subjek penelitian yang masuk dalam kategori cukup baik, kurang baik, dan tidak baik.

Nocking, berdasarkan analisis data dengan bantuan software komputer diperoleh rerata kinerja gerak teknik memanah pada tahap nocking sebesar $=4,00$. Adapun distribusi kinerja gerak teknik memanah untuk tahap nocking pada atlet panahan PPLP DIY berdasarkan pengkategoriannya dapat dilihat pada Tabel 5 .

Tabel 5. Distribusi kinerja gerak teknik memanah pada tahap nocking

\begin{tabular}{lccl}
\hline Interval skor & $\mathrm{F}$ & Persentase & Kategori \\
\hline 3,26 s.d 4,00 & 3 & $100 \%$ & Baik \\
2,57 s.d 3,25 & 0 & $0 \%$ & Cukup baik \\
1,76 s.d 2,50 & 0 & $0 \%$ & Kurang baik \\
1,00 s.d 1,75 & 0 & $0 \%$ & Tidak baik \\
\hline
\end{tabular}

Data pada Tabel 5 memperlihatkan bahwa kinerja gerak teknik memanah untuk tahap nocking atlet puteri PPLP DIY pada nomor 70 meter recurve, 3 atlet sebagai subjek penelitian $(100 \%)$ berada pada kategori baik, tidak ada subjek penelitian yang masuk dalam kategori cukup baik, kurang baik, dan tidak baik.

Set $U p$, berdasarkan analisis data dengan bantuan software komputer diperoleh rerata kinerja gerak teknik memanah pada tahap set up sebesar $=4,00$. Adapun distribusi kinerja gerak teknik memanah untuk tahap set up pada atlet panahan PPLP DIY berdasarkan pengkategoriannya dapat dilihat pada Tabel 6.

Tabel 6. Distribusi kinerja teknik memanah pada tahap set up.

\begin{tabular}{cccl}
\hline Interval skor & F & Persentase & Kategori \\
\hline 3,26 s.d 4,00 & 3 & $100 \%$ & Baik \\
2,57 s.d 3,25 & 0 & $0 \%$ & Cukup baik \\
1,76 s.d 2,50 & 0 & $0 \%$ & Kurang baik \\
1,00 s.d 1,75 & 0 & $0 \%$ & Tidak baik \\
\hline
\end{tabular}

Tabel 6 memperlihatkan bahwa kinerja gerak teknik memanah untuk tahap set up atlet puteri PPLP DIY pada nomor 70 meter recurve, 3 atlet sebagai subjek penelitian (100\%) berada pada kategori baik, tidak ada subjek penelitian yang masuk dalam kategori cukup baik, kurang baik, dan tidak baik.

Drawing, berdasarkan analisis data dengan bantuan software komputer diperoleh rerata kinerja gerak teknik memanah pada tahap drawing sebesar $=3,58$. Adapun distribusi kinerja gerak teknik memanah untuk tahap drawing pada atlet panahan PPLP DIY berdasarkan pengkategoriannya dapat dilihat pada Tabel 7.

Tabel 7. Distribusi kinerja gerak teknik memanah pada tahap drawing.

\begin{tabular}{cccl}
\hline Interval skor & F & Persentase & Kategori \\
\hline 3,26 s.d 4,00 & 2 & $66,70 \%$ & Baik \\
2,57 s.d 3,25 & 1 & $33,30 \%$ & Cukup baik \\
1,76 s.d 2,50 & 0 & $0 \%$ & Kurang baik \\
1,00 s.d 1,75 & 0 & $0 \%$ & Tidak baik \\
\hline
\end{tabular}

Tabel 7 memperlihatkan bahwa kinerja gerak teknik memanah untuk tahap drawing atlet puteri pplp diy pada jarak 70 meter recurve dari 3 atlet sebagai subjek penelitian, 2 di antaranya dengan persentase $66,7 \%$ berada pada kategori baik, 1 subjek penelitian dengan persentae 33,3\% masuk dalam kategori cukup baik, tidak ada penelitian yang masuk dalam kategori kurang baik, dan tidak baik.

Anchoring, berdasarkan analisis data dengan bantuan software komputer diperoleh rerata kinerja gerak teknik memanah pada ta- 
hap anchoring sebesar=3,83. Adapun distribusi kinerja gerak Teknik memanah untuk tahap anchoring pada atlet panahan pplp diy berdasarkan pengkategoriannya dapat dilihat pada Tabel 8.

Tabel 8. Distribusi kinerja gerak teknik memanah pada tahap anchoring berdasarkan pengkategoriannya

\begin{tabular}{cccl}
\hline Interval skor & F & Persentase & Kategori \\
\hline 3,26 s.d 4,00 & 2 & $66,70 \%$ & Baik \\
2,57 s.d 3,25 & 1 & $33,30 \%$ & Cukup baik \\
1,76 s.d 2,50 & 0 & $0 \%$ & Kurang baik \\
1,00 s.d 1,75 & 0 & $0 \%$ & Tidak baik \\
\hline
\end{tabular}

Tabel 8 memperlihatkan bahwa kinerja gerak teknik memanah untuk tahap anchoring atlet puteri PPLP DIY pada nomor 70 meter recurve dari 3 atlet sebagai subjek penelitian 2 di antaranya dengan persentase $66,7 \%$ berada pada kategori baik, 1 subjek penelitian dengan persentae 33,3\% masuk dalam kategori cukup baik, tidak ada penelitian yang masuk dalam kategori kurang baik dan tidak baik.

Holding, berdasarkan analisis data dengan bantuan software komputer diperoleh rerata kinerja gerak teknik memanah pada tahap holding sebesar=3,67. Adapun distribusi kinerja gerak teknik memanah untuk tahap holding pada atlet panahan PPLP DIY berdasarkan pengkategoriannya dapat dilihat pada Tabel 9.

Tabel 9. Distribusi kinerja gerak teknik memanah pada tahap holding.

\begin{tabular}{cccl}
\hline Interval skor & F & Persentase & Kategori \\
3,26 s.d 4,00 & 2 & $66,70 \%$ & Baik \\
2,57 s.d 3,25 & 1 & $33,30 \%$ & Cukup baik \\
1,76 s.d 2,50 & 0 & $0 \%$ & Kurang baik \\
1,00 s.d 1,75 & 0 & $0 \%$ & Tidak baik \\
\hline
\end{tabular}

Tabel 9 memperlihatkan bahwa kinerja gerak teknik memanah pada tahap holding atlet puteri PPLP DIY pada nomor 70 meter recurve, 3 atlet sebagai subjek penelitian 2 di antaranya dengan persentase $66,7 \%$ berada pada kategori baik, 1 subjek penelitian dengan persentae 33,3\% masuk dalam kategori cukup baik, tidak ada penelitian yang masuk dalam kategori kurang baik dan tidak baik.

Aiming, berdasarkan analisis data dengan bantuan software komputer diperoleh rerata kinerja gerak teknik memanah pada tahap aiming sebesar $=3,67$. Adapun distribusi kiner- ja gerak teknik memanah untuk tahap aiming pada atlet panahan PPLP DIY berdasarkan pengkategoriannya dapat dilihat pada Tabel 10.

Tabel 10. Distribusi kinerja gerak teknik memanah pada tahap aiming

\begin{tabular}{cccl}
\hline Interval skor & F & Persentase & Kategori \\
\hline 3,26 s.d 4,00 & 2 & $66,70 \%$ & Baik \\
2,57 s.d 3,25 & 1 & $33,30 \%$ & Cukup baik \\
1,76 s.d 2,50 & 0 & $0 \%$ & Kurang baik \\
1,00 s.d 1,75 & 0 & $0 \%$ & Tidak baik \\
\hline
\end{tabular}

Tabel 10 memperlihatkan bahwa kinerja gerak teknik memanah pada tahap aiming atlet puteri PPLP DIY pada nomor 70 meter recurve, dari 3 atlet sebagai subjek penelitian 2 di antaranya dengan persentase $66,7 \%$ berada pada kategori baik, 1 subjek penelitian dengan persentae 33,3\% masuk dalam kategori cukup baik, tidak ada penelitian yang masuk dalam kategori kurang baik dan tidak baik.

Release, berdasarkan analisis data dengan bantuan software komputer diperoleh rerata kinerja gerak teknik memanah pada tahap release sebesar $=3,67$. Adapun distribusi kinerja gerak teknik memanah untuk tahap release pada atlet panahan PPLP DIY berdasarkan pengkategoriannya dapat dilihat pada Tabel 11

Tabel 11. Distribusi kinerja gerak teknik memanah pada tahap release

\begin{tabular}{lccl}
\hline Interval skor & F & Persentase & Kategori \\
\hline 3,26 s.d 4,00 & 2 & $66,70 \%$ & Baik \\
2,57 s.d 3,25 & 1 & $33,30 \%$ & Cukup baik \\
1,76 s.d 2,50 & 0 & $0 \%$ & Kurang baik \\
1,00 s.d 1,75 & 0 & $0 \%$ & Tidak baik \\
\hline
\end{tabular}

Tabel 11 memperlihatkan bahwa kinerja gerak teknik memanah pada tahap release atlet puteri PPLP DIY pada nomor 70 meter recurve, dari 3 atlet sebagai subjek penelitian 2 di antaranya dengan persentase $66,7 \%$ berada pada kategori baik, 1 subjek penelitian dengan persentase 33,3\% masuk dalam kategori cukup baik, tidak ada penelitian yang masuk dalam kategori kurang baik dan tidak baik.

Follow through, berdasarkan analisis data dengan bantuan software komputer diperoleh rerata kinerja gerak teknik memanah pada tahap follow through sebesar=3,89. Adapun distribusi kinerja gerak teknik memanah untuk tahap follow through pada atlet panahan PPLP 
DIY berdasarkan pengkategoriannya dapat dilihat pada Tabel 12.

Tabel 12. Distribusi kinerja gerak teknik memanah pada tahap follow through

\begin{tabular}{cccl}
\hline Interval skor & F & Persentase & Kategori \\
\hline 3,26 s.d 4,00 & 3 & $100 \%$ & Baik \\
2,57 s.d 3,25 & 0 & $0 \%$ & Cukup baik \\
1,76 s.d 2,50 & 0 & $0 \%$ & Kurang baik \\
1,00 s.d 1,75 & 0 & $0 \%$ & Tidak baik \\
\hline
\end{tabular}

Tabel 12 memperlihatkan bahwa kinerja gerak teknik memanah untuk tahap followthrough atlet puteri PPLP DIY pada nomor 70 meter recurve, 3 atlet sebagai subjek penelitian $(100 \%)$ berada pada kategori baik; tidak ada subjek penelitian yang masuk dalam kategori cukup baik, kurang baik, dan tidak baik.

Pada analisis performa atlet, setelah dianalisis dengan bantuan software kinovea, maka dapat diketahui kepadatan gerak (movement density) pada saat melakukan tarikan selama kejuaraan. Kepadatan gerak (movement density) pada analisis data dalam penelitian ini merupakan jumlah waktu keseluruhan yang digunakan oleh atlet pada saat melakukan gerakan memanah. Hasil dari perhitungan tersebut dapat dipaparkan sebagai berikut:

Tabel 13. Movement density

\begin{tabular}{lccccc}
\hline Testi & $\begin{array}{c}\text { Jumlah } \\
\text { seluruh } \\
\text { jeda }\end{array}$ & $\begin{array}{c}\text { Jumlah } \\
\text { waktu } \\
\text { tarikan }\end{array}$ & $\begin{array}{c}\text { Rata- rata } \\
\text { waktu } \\
\text { tarikan }\end{array}$ & $\begin{array}{c}\text { Jum- } \\
\text { lah } \\
\text { tarikan }\end{array}$ & $\begin{array}{c}\text { Move- } \\
\text { ment } \\
\text { density }\end{array}$ \\
\hline Rsn & 1163,48 & 314,09 & 7,91 detik & 47 & $25,80 \%$ \\
Fn & 1078,02 & 361,98 & 8,42 detik & 43 & $25,10 \%$ \\
Fnd & 975,52 & 464,48 & 8,76 detik & 53 & $32,30 \%$ \\
\hline
\end{tabular}

Berdasarkan data yang terpapar pada tabel dapat diketahui bahwa testi 1 menggunakan waktu untuk menarik busur melakukan gerakan memanah selama pertandingan sebanyak 314,09 detik, dengan persentase dari keseluruhan waktu sebesar $25,8 \%$. Testi 2 menggunakan waktu untuk melakukan gerakan memanah selama pertandingan sebanyak 361,98 detik, dengan persentase dari keseluruhan waktu sebesar $25,1 \%$. Testi 3 menggunakan waktu untuk melakukan gerakan memanah selama pertandingan sebanyak 364,48 detik, dengan persentase dari keseluruhan waktu sebesar $32,3 \%$. Sehingga testi 3 mempunyai movement density tertinggi, dan jeda terendah. Sedangkan testi 2 mempunyai movement density terendeh, dan jeda tertingga.
Rata-rata waktu tarikan berturut-turut testi 1, 2 dan 3 adalah 7,91 detik, 8, 42 detik, dan 8,76 detik. Dari rata-rata tersebut dapat diketahui bahwa pada setiap tarikan testi 1 menghabiskan waktu paling cepat, sedangkan testi 3 menghabiskan waktu terlama pada setiap tarikan. Sedangkan untuk jumlah tarikan selama pertandingan berturut-turut testi 1, 2 dam 3 adalah 47 kali, 43 kali, dan 53 kali. Tarikan terbanyak dilakukan oleh testi 3, sedangkan testi 2 melakukan tarikan paling sedikit.

Hasil perolehan skor testi 1 pada seluruh rambahan dapat dipaparkan sebagai berikut:

Tabel 14. Perolehan Skor Testi 1

\begin{tabular}{ccccccc}
\hline \multirow{2}{*}{ Testi } & \multicolumn{5}{c}{ Rambahan } \\
\cline { 2 - 6 } & 1 & 2 & 3 & 4 & 5 & 6 \\
\hline \multirow{4}{*}{1} & 10 & 10 & 9 & 10 & 9 & 10 \\
& 10 & 10 & 9 & 10 & 9 & 9 \\
& 9 & 10 & 9 & 9 & 9 & 7 \\
& 9 & 9 & 8 & 9 & 7 & 6 \\
& 9 & 5 & 8 & 8 & 7 & 5 \\
\hline Jumlah & 54 & 47 & 51 & 53 & 46 & 42 \\
\hline
\end{tabular}

Dari paparan data pada tabel 14 dapat diketahui perolehan skor selama pertandingan dari testi 1 . Hasil analisis menunjukkan bahwa perolehan skor selama pertandingan yang dilakukan oleh testi 1 tidak mengalami penurunan pada hasil setiap rambahan, yaitu jumlah sekor pada setiap rambahan dari rambahan 1 sampai 6 berturut-turut adalah 54, 47, 51, 53, 46 dan 42. Namun pada setiap rambahan perolehan skor pada setiap tembakan selalu menurun setelah beberapa kali tembakan. Pada rambahan 1 skor menurun pada tembakan ke 3, dan kembali menurun pada tembakan ke 6 . Perolehan berturut-turut dari tembakan pertama hingga ke enam yaitu 10, 10, 9, 9, 9, dan 7. Pada rambahan ke 2 skor selalu menurun mulai dari tembakan ke 4 . Perolehan berturutturut dari tembakan pertama hingga ke enam yaitu 10, 10, 10, 9, 5, dan 3. Pada rambahan ke 3 skor menurun pada tembakan ke 4 dan bertahan hingga tembakan ke 6 . Perolehan berturutturut dari tembakan pertama hingga ke enam yaitu 9, 9, 9, 8, 8, dan 8. Pada rambahan ke 4 skor menurun pada tembakan ke 3, kemudian menurun pada tembakan ke 5, pada tembakan ke 6 perolehan skor kembali menurun. Perolehan berturut-turut dari tembakan pertama hingga ke enam yaitu 10,10, 9, 9, 8, dan 7. Pada rambahan ke 5 skor menurun pada tembakan ke 4 dan kembali menurun pada tembakan ke 
6. Perolehan berturut-turut dari tembakan pertama hingga ke enam yaitu 9, 9, 9, 7, 7, dan 5 . Pada rambahan ke 6 skor menurun berturutturut dari tembakan ke 2 sampai tembakan ke 5. Perolehan berturut-turut dari tembakan pertama hingga ke enam yaitu 10, 9, 7, 6, 5, dan 5 . Hasil perolehan skor testi 2 pada seluruh rambahan dapat dipaparkan sebagai berikut:

Tabel 15. Perolehan Skor Testi 2

\begin{tabular}{ccccccc}
\hline \multirow{2}{*}{ Testi } & \multicolumn{6}{c}{ Rambahan } \\
\cline { 2 - 7 } & 1 & 2 & 3 & 4 & 5 & 6 \\
\hline \multirow{6}{*}{2} & 10 & 10 & 7 & 9 & 10 & 9 \\
& 9 & 9 & 7 & 9 & 9 & 8 \\
& 7 & 8 & 5 & 9 & 7 & 8 \\
& 7 & 7 & 5 & 8 & 5 & 7 \\
& 4 & 6 & 4 & 7 & 4 & 5 \\
\hline \multirow{3}{*}{ Jumlah } & 45 & 47 & 32 & 50 & 40 & 43 \\
\hline
\end{tabular}

Dari data tabel dapat diketahui perolehan skor selama pertandingan oleh testi 2 . Hasil analisis menunjukkan bahwa perolehan skor selama pertandingan yang dilakukan oleh testi 2 tidak mengalami penurunan pada hasil jumlah setiap rambahan, yaitu jumlah sekor pada setiap rambahan dari rambahan 1 sampai 6 berturut-turut adalah 45, 47, 51, 32, 40 dan 43 . Namun pada setiap skor pada setiap tembakan selalu menurun setelah beberapa kali tembakan.

Pada rambahan 1 skor menurun pada tembakan ke 2 sampai tembakan ke 4, dan kembali menurun pada tembakan ke 6. Perolehan berturut-turut dari tembakan pertama hingga ke enam yaitu 10, 9, 8, 7, 7, dan 4. Pada rambahan ke 2 skor menurun pada tembakan ke 2 sampai tembakan ke 4, dan kembali menurun pada tembakan ke 6. Perolehan berturut-turut dari tembakan pertama hingga ke enam yaitu $10,9,8,7,7$, dan 6. Pada rambahan ke 3 skor menurun pada tembakan ke 3 dan ke 5. Perolehan berturut-turut dari tembakan pertama hingga ke enam yaitu $7,7,5,5,4$, dan 4 . Pada rambahan ke 4 skor menurun pada tembakan ke 4, kemudian menurun pada tembakan ke 6 .

Perolehan berturut-turut dari tembakan pertama hingga ke enam yaitu 9, 9, 9, 8, 8, dan 7. Pada rambahan ke 5 skor menurun pada tembakan ke 2 sampai tembakan 4 kembali menurun pada tembakan ke 6. Perolehan berturut-turut dari tembakan pertama hingga ke enam yaitu 10, 9, 7, 5, 5, dan 4 . Pada rambahan ke 6 skor menurun berturut-turut dari tem- bakan ke 3 sampai tembakan ke 6 . Perolehan berturut-turut dari tembakan pertama hingga ke enam yaitu 9, 9, 8, 7, 6, dan 5 .

Hasil perolehan skor testi 3 pada seluruh rambahan dapat dipaparkan sebagai berikut:

Tabel 16. Perolehan Skor Testi 3

\begin{tabular}{ccccccc}
\hline \multirow{2}{*}{ Testi } & \multicolumn{6}{c}{ Rambahan } \\
\cline { 2 - 7 } & 1 & 2 & 3 & 4 & 5 & 6 \\
\hline \multirow{4}{*}{3} & 9 & 10 & 9 & 10 & 10 & 10 \\
& 8 & 9 & 8 & 9 & 10 & 8 \\
& 7 & 9 & 8 & 8 & 10 & 8 \\
& 5 & 8 & 8 & 7 & 6 & 7 \\
& 7 & 7 & 5 & 5 & 6 \\
Jumlah & 36 & 49 & 46 & 43 & 44 & 44 \\
\hline
\end{tabular}

Dari data tabel dapat diketahui perolehan skor selama pertandingan oleh testi 3. Setelah dianalisis perolehan skor selama pertandingan yang dilakukan oleh testi 3 tidak mengalami penurunan pada hasil setiap rambahan, yaitu jumlah sekor pada setiap rambahan dari rambahan 1 sampai 6 berturut-turut adalah 36, 49, 46, 43, 44 dan 44. Namun pada setiap rambahan perolehan skor pada setiap tembakan selalu menurun setelah beberapa kali tembakan.

Pada rambahan 1 skor menurun pada tembakan ke 2 dan 3, kemudian kembali menurun pada tembakan ke 5. Pada tembakan ke 6 testi 3 mengalami missing, yaitu tidak mendapatkan skor karena anak panah menancap di luar target face. Perolehan skor berturut-turut dari tembakan pertama hingga ke enam yang dilakukan oleh testi 3 yaitu 9, 8, 7, 7, 5, dan 0 . Pada rambahan ke 2 skor menurun pada tembakan ke 2, kemudian menurut pada temakan ke 4, 5 dan 6. Perolehan berturut-turut dari tembakan pertama hingga ke enam yaitu 10, 9, $9,8,7$, dan 6. Pada rambahan ke 3 skor menurun pada tembakan ke 2 dan kebali menurun pada tembakan ke 5 dan 6 . Perolehan berturutturut dari tembakan pertama hingga ke enam yaitu 9, 8, 8, 8, 7, dan 6. Pada rambahan ke 4 skor menurun pada setiap tembakan. Perolehan berturut-turut dari tembakan pertama hingga ke enam yaitu 10, 10, 9, 8, 7, 5, dan 4 . Pada rambahan ke 5 skor menurun pada tembakan ke 4, 5 dan 6. Perolehan berturut-turut dari tembakan pertama hingga ke enam yaitu 10, 10, 10, 6, 5, dan 3. Pada rambahan ke 6 skor menurun dari tembakan ke 2, kemudian menurun ppada tembakan ke 4,5 dan 6 . Pe- 
rolehan berturut-turut dari tembakan pertama hingga ke enam yaitu 10,8,8, 7, 6, dan 5 .

Analisis untuk kinerja memanah pada ketiga testi di atas masuk dalam kategori baik. Dari tahap stance, knocking, set up, drawing, anchoring, holding, aiming, release hingga followtrogh secara keseluruhan telah masuk dalam kategori baik. Movement dencity secara keseluruah dari testi 1, 2 dan 3 berturut-turut hanya $25,8 \%, 25,1 \%, 32 \%$ dari keseluruhan waktu bertanding. Dilihat dari hasil persentase tersebut yang paling efektif dalam melakukan gerakan adalah testi 2, karena memilik persentasi movement density paling sedikit.

Pada analisis di atas terlihat penguasaan teknik seluruh testi dalam kategori baik, namun penguasaan teknik saja tidak cukup untuk mendapatkan prestasi yang optimal. Tabel perolehan skor dari tembakan pertama hingga ke enam pada setiap rambahan menunjukkan bahwa performa pada atlet menurun karena menarik tali busur berkali-kali dengan beban tarikan 42 pound untuk testi 1 dan 40 pound untuk testi 2 . Hal tersebut menegaskan sebuah performa yang optimal tidak hanya dipengaruhi oleh unsur teknik.

Hukum Newton I sebagaimana dirumuskan oleh Sir Isaac adalah: "Sebuah benda terus dalam keadaan diam atau terus bergerak dengan kelajuan tetap, kecuali jika ada gaya luar yang memaksa benda tersebut mengubah keadaan." (Nukhrawi, 2011) Hukum I Newton juga menggambarkan sifat benda yang selalu mempertahankan keadaan diam atau keadaan bergeraknya yang dinamakan inersia atau kelembaman. Oleh karena itu, Hukum I Newton dikenal juga dengan sebutan Hukum Kelembaman. Hukum ini mulai diterapkan dari mulai menarik busur, terutama dari sikap set up. Pemanah tidak bisa hanya menggunakan otot bagian belakang saja dalam menarik, tetapi harus menggunakan lengan atas dan tangan penarik. Bagaimanapun juga, jika pemanah secara kontinu menarik, berarti melepas posisi holding, yang memungkinkan dari lengan atas dan tangan penarik ke otot bagian belakang. Oleh karena itu, jika holding tidak tercapai, tidak ada transfer ketegangan yang bisa terjadi. Selama fase transfer, otot punggung secara kontinyu menggerakkan scapula ke arah tulang belakang, ketika ketegangan dari lengan atas dan tangan penarik telah ditransfer. Hukum inertia hanya diterapkan dari posisi holding. Scapulae bergerak mendekat tulang belakang yang menyebabkan dada membuka dan tidak berlebihan, ini penting supaya anak panah terjadi klik. Hukum

Newton II berbunyi: "Benda akan mengalami percepatan jika ada gaya yang bekerja pada benda tersebut dimana gaya ini sebanding dengan suatu konstanta (massa) dan percepatan benda". (Nawir, 2011: p.127), maksudnya, makin besar percepatan makin besar pula kekuatannya, makin kecil percepatan makin kecil pula kekuatannya. Hukum ini akan menerapkan momentum dari memulai gerakan menarik. Dengan demikian lebih baik menarik yang cepat dandalam garis lurus kira-kira 2-3 inchi di bawah dagu. Hukum Newton III berbunyi: "Dua benda yang berinteraksi akan timbul gaya pada masing-masing benda yang arahnya berlawanan arah dan besarnya sama". (Nawir, 2011: p.128), dalam hukum ini dijelaskan mengenai aksi dan reaksi. Di mana pada saat proses release, aksi yang diberikan ialah pada saat otot-otot scapula bekerja menarik tali kebelakang yang menghasilkan suatu reaksi yang disebut proses klicking, sehingga membuat anak panah terlepas dari busur. Dalam proses release, juga menuntut adanya keseimbangan statis yang harus dipertahankan selama menembak.

Pelatih harus dapat mengidentifikasi unsur-unsur lain untuk mengahsilkan atlet yang dapat mencapai performa optimal khususnya dalam cabang olahraga panahan. Beberapa unsur-unsur tersebut di antaranya: (1) kesegaran jasmani/ kemampuan fisik khususnya kekuatan dan daya tahan otot lengan; (2) faktor keterampilan/teknik meliputi; koordinasi gerak, keindahan gerak, waktu reaksi, dan sebagainya; dan (3) faktor pembawaan fisik seperti; segi-segi antrophometrik: tinggi dan berat badan, panjang lengan, tungkai, lebar bahu, kemampuan gerak, dan lain sebagainya.

Persiapan fisik harus dianggap sebagai salah satu aspek yang harus diperhatikan dan dipertimbangkan dalam latihan untuk mencapai prestasi maksimal, (Ismoko \& Sukoco, 2013, p.2). Aspek kondisi fisik merupakan bagian terpenting dalam semua cabang olahraga, terutama untuk mendukung aspek-aspek lainnya seperti teknik, taktik dan mental. Kondisi fisik sangat menentukan dalam mendukung tugas atlet dalam latihan maupun pertandingan sehingga diharapakan dengan mempunyai kondisi fisik yang bagus performa dapat ditampilkan secara maksimal, (Ismoko \& Sukoco, 2013) Latihan fisik merupakan dasar bagi tubuh untuk beradaptasi pada situasi pertandinan, seperti iklim/cuaca, wilayah/lokasi pertandingan, dan sebagainya karena kondisi 
fisik merupakan kondisi organ tubuh untuk menerima dan menjalankan aktivitas yang dituntut terutama selama pertandingan dalam kondisi apapun.

\section{SIMPULAN}

Berdasarkan perolehan data dan hasil penelitian, dapat disimpulkan bahwa: (1) Kinerja gerak teknik memanah atlet panahan putri PPLP DIY pada tahap cara berdiri (stance), memasang ekor panah (nocking), posisi setengah tarikan (set up), menarik tali (drawing), penjangkaran (anchoring), menahan sikap memanah (holding), membidik (aiming), melepaskan anak panah (release) dan gerak lanjut (follow through) berada pada kategori baik. (2) Performa yang dimiliki oleh atlet panahan putri PPLP DIY masih tergolong kurang untuk olahraga panahan. Hal tersebut dapat diamati dari perolehan skor saat bertanding. Hasil pencatatan skor pada saat pertandingan menunjukkan bahwa perolehan skor pada setiap tembakan ketiga atlet mengalami penurunan. Ada beberapa kali tembakann yang skornya tetap sama dengan skor tembakan sebelumnya, namun perolehan skor tersebut tidak pernah mengalami kenaikan dari skor sebelumnya. Ini menunjukkan bahwa kekuatan fisik atlet panahan harus dilatih secara terprogram. Sehingga hasil atau nilai tembakan menjadi konsisten.

\section{DAFTAR PUSTAKA}

Artanayasa, I. (2015). Panahan. Surabaya: Graha Ilmu Panahan.

Azwar, S. (2008). Penyusunan skala psikologi. Yogyakarta: Pustaka Pelajar.

Curran, S. A., \& Frossard, L. (2012). Biomechanical analysis of the performance of paralympians: From foundation to elite level. Journal Prothetics and Orthotics
International, 36 (3). 1-22.

Furqon, et. al. (2003). Analisis Kebutuhan Fisik dan Implikasi Latihan dalam Olahraga Panahan. Jurnal IPTEK Olahraga, 45-49.

Hamill, J., \& Knutzen, K. M. (2003). Biomecanical basic of human movement. Amerika Serikat: Lippincott Williams \& Wilkins.

Hmill, J. a. (2019). Biomekanika Dasar Gerakan Manusia Dengan Ilustrasi Ergonomik Ortopedik dan Latihan Edisi 4 Original. Amerika Serikat: Human Kinetics Publisher (UK).

Ihor, Z. (2008). Modeling and computer simulation of bow stabilization in thevertical plane. International journal of sport science and engineering, Vol 2. No. 1, pp. 3-14.

Ismoko, \& Sukoco. (2013, p.2). 'Pengaruh Metode Latihan dan Koordinasi terhadap Power Tungkai' . Journal Keolahragaan, vol 1,no 1,hlm 1-12.

Knudson, D. (2007). Fundamental of biomechanics. California State University at Chico: Springer Science \& Business Media.

Komarudin. (2013). Psikologi Olah Raga. Bandung : PT Remaja Rosda Karya .

Lee, H. K. (2009). Evaluation of attention and relaxation levels of Archers in shooting process using brain wave signal analysis algorithms. Journal Neuro Sky Inc, 12, No 3, pp.341-350.

Muchtamadji, A. (1999). Olahraga Panahan Ronde Tembak Sasaran. FPOK IKIP Bandung: PT Grafindo Media Pratama.

Nasution, Y. (2003). Latihan konsentrasi Bahan diskusi psikologi olahraga bagi pelatih dalam rangka Pelatnas SEA Games tahun 2003. Yogyakarta: Rajagrafindo Persada.

Nukhrawi, N. (2011). Kontribusi kekuatan otot tangan dan daya otot lengan dengan kemampuan memanah jarak 30 meter pada atlet panahan Sulawesi Selatan. Jurnal, Competitor, Edisi 3, 122-132.

Pelana, R., \& Oktafiranda, N. D. (2010). Buku Teknik Dasar Olahraga Panahan. Depok: PT Raja Grafindo Persada. Prasetyo.

Prasetyo, Y. (2019). Teknik Dasar Panahan Trik Jitu Menembak Akurat dan Tepat Sasaran. Jakarta : Republika.

Rushall, B. (2007). Mental skills training for serious athletes. California USA : Sports Science Associates .

Sandjaja,Hariyanto, \& Albertus. (2006). Panduan penelitian. Jakarta: Prestasi Pustaka.

Sudarmada, I., \& Kusuma, I. (2015). Biomekanika Olahraga. Jakarta Pusat: Graha Ilmu dan Undiksha Press 